\title{
Uji Tipe dan Ketinggian Perangkap untuk Mengendalikan Penggerek Buah Kopi Hypothenemus hampei Ferr. (Coleoptera : Scolytidae) di Desa Pegagan Julu II Kecamatan Sumbul Kabupaten Dairi
}

Test of Type and Height of Trap to Control Coffee Berry Borrer Hypothenemus hampei Ferr. (Coleoptera : Scolytidae) in Pegagan Julu II village, Sub-district Sumbul, District Dairi

Winda Nuraini Situmorang*, Marheni dan Ameilia Zuliyanti Siregar

Program Studi Agroteknologi, Fakultas Pertanian USU, Medan - 20155

*Corresponding author: winda.stmg@gmail.com

\begin{abstract}
Coffee berry borer (Hypothenemus hampei) is one of the dominant pests that are difficult to control. This research was conducted to determine the effectiveness type and height of trap to control coffee berry borer in Sumbul, Dairi. The method used Factorial Randomized Block Design (RBD) which consisted 2 treatments factor and four replications. The first factor was type of trap (single funnel trap, multiple funnel trap, and mineral bottle) and the second factor was the height of trap $(60 ; 120$ ; 175 ; and $200 \mathrm{~cm}$ ). The results showed that the type, height and interactions was significant by coffee berry borer trapped. The best trap used by mineral bottle with height $60 \mathrm{~cm}$ is 2.75 beetles. The type of trap significant by the number of insects trapped and residue of attractant while height and interaction non significant. The best trap of insects trapped was mineral bottle with height 175 $\mathrm{cm}$ is 21.8 individuals and the highest insect consisted by Formicidae amounted to 231 individuals with the residue of attractant is $0.73 \mathrm{ml}$.
\end{abstract}

Keywords: type, height, Hypothenemus hampei Ferr.

\section{ABSTRAK}

Penggerek buah kopi (Hypothenemus hampei) merupakan salah satu hama dominan yang sulit dikendalikan. Penelitian ini bertujuan untuk mengetahui tipe dan ketinggian yang efektif dalam mengendalikan penggerek buah kopi di Sumbul, Dairi. Penelitian ini dilaksanakan pada bulan Januari sampai dengan Februari 2017. Penelitian menggunakan Rancangan Acak Kelompok (RAK) faktorial dengan 2 faktor perlakuan dan empat ulangan. Faktor pertama adalah tipe perangkap (corong tunggal, corong ganda, dan botol air mineral). Faktor kedua adalah ketinggian perangkap $(60,120,175,200 \mathrm{~cm})$. Hasil analisis data menunjukkan bahwa faktor tipe, ketinggian serta interaksi berbeda nyata terhadap jumlah penggerek buah kopi dengan perangkap terbaik menggunakan tipe botol air mineral ketinggian $60 \mathrm{~cm}$ yaitu 27,5 ekor. Faktor tipe berbeda nyata dengan jumlah serangga lain dan sisa larutan, tetapi tidak berbeda nyata terhadap ketinggian dan interaksi. Perangkap terbaik untuk serangga lain adalah tipe botol air mineral ketinggian $175 \mathrm{~cm}$ yaitu 21,8 ekor dengan ordo terbanyak adalah Formicidae yaitu 231 ekor dengan sisa larutan yaitu $0,73 \mathrm{ml}$.

Kata Kunci: tipe perangkap, ketinggian perangkap, penggerek buah kopi

\section{PENDAHULUAN}

Kopi termasuk komoditas perkebunan yang banyak diperdagangkan di dunia internasional. Indonesia merupakan urutan keempat penghasil kopi terbesar setelah Brasil, Vietnam dan Kolombia. Di Indonesia, tepatnya kabupaten Dairi Sumatera Utara adalah penghasil kopi terbanyak dan berbasis ekspor (Panggabean, 2011).

Kabupaten Dairi merupakan sentra penghasil kopi arabika terbesar di Sumatera Utara. Kecamatan Sumbul sebagai daerah yang memproduksi kopi arabika terbanyak di 
Dairi. Sekitar 95\% penduduk di Kecamatan Sumbul sebagai petani kopi dan buruh tani serta menjadikan usahatani kopi sebagai usaha tani primadona di daerah tersebut (Kecamatan Sumbul Dalam Angka, 2016).

Berdasarkan data Kabupaten Dairi Dalam Angka (2014), produksi kopi arabika pada tahun 2010-2013 mengalami penurunan pada tahun 2014 yaitu dari 9.583 ton menjadi 8.621 ton. Hal ini juga berpengaruh terhadap volume ekspor disebabkan menurunnya produktivitas.

Produktivitas yang rendah tersebut bisa disebabkan oleh beberapa faktor antara lain kurangnya pemahaman petani kopi tentang budidaya kopi, rendahnya dosis pupuk, kurangnya pemeliharaan tanaman, tidak adanya tanaman penaung, tuanya umur tanaman, dan tingginya serangan hama penggerek buah kopi/PBKo (Hypothenemus hampei) (Malau et al.,2012).

Intensitas serangan PBKo yang tinggi di Sumatera Utara dapat menurunkan produksi dan mutu kopi. Hal tersebut disebabkan oleh beberapa alasan antara lain kelangkaan ketersediaan atraktan dari bahan buatan dan ketidakpahaman petani dalam merawat tanaman kopi. Bahan-bahan buatan dapat berupa methanol dan etanol yang berfungsi sebagai atraktan. Perkembangan PBKo sangat pesat pada kebun yang tidak terawat oleh petani. Petani yang tidak memahami perawatan kesehatan tanaman memberikan kesempatan bagi hama untuk berkembang dengan pesat (Manurung, 2008).

Berdasarkan penelitian sebelumnya oleh Wiryadiputra dari Puslitkoka (2006), kajian tentang perangkap untuk hama penggerek buah kopi telah dilakukan untuk mengevaluasi aspek warna perangkap, desain atau tipe perangkap dan senyawa penarik yang paling efektif untuk menarik serangga penggerek buah kopi serta potensinya dalam menurunkan populasi hama penggerek buah kopi dengan meletakkan perangkap pada tiang kayu pada ketinggian sekitar $175 \mathrm{~cm}$ di atas permukaan tanah dan ditempatkan di antara pohon kopi.

Berdasarkan uraian di atas, penulis tertarik untuk melakukan penelitian mengenai pengendalian penggerek buah kopi berkaitan dengan tipe perangkap dan ketinggian perangkap.

\section{BAHAN DAN METODE}

Penelitian ini dilaksanakan di kebun kopi milik petani di Desa Pegagan Julu II Kecamatan Sumbul, Kabupaten Dairi dengan ketinggian tempat \pm 1.066 meter di atas permukaan laut. Penelitian dilaksanakan dari bulan Januari sampai dengan Februari 2017.

Adapun bahan yang digunakan adalah tanaman kopi arabika (Coffea arabica) sebagai tanaman percobaan, senyawa penarik methanol dan ethanol dengan perbandingan 3:1, alkohol, deterjen, botol bekas air mineral, corong, botol kocok, pinset, plastik, bambu, tali, pisau, meteran.

Penelitian ini menggunakan Rancangan Acak Kelompok (RAK) faktorial dengan perlakuan sebagai berikut; Faktor I : Tipe Perangkap (P), P1 : Perangkap corong tunggal, P2 : Perangkap corong ganda, P3 : Perangkap botol bekas air mineral. Faktor yang kedua adalah; Tinggi Perangkap (T), T1 : Perangkap dengan ketinggian $60 \mathrm{~cm}, \mathrm{~T} 2$ : Perangkap dengan ketinggian $120 \mathrm{~cm}, \mathrm{~T} 3$ : Perangkap dengan ketinggian $175 \mathrm{~cm}$, T4 : Perangkap dengan ketinggian $200 \mathrm{~cm}$

\section{Pelaksanaan Penelitian Survei Lokasi Penelitian}

Survei dilakukan dengan mengamati daerah pertanaman kopi di kebun milik petani. Jenis kopi pada areal percobaan adalah kopi arabika berumur 4 tahun. Ditetapkan luas lahan penelitian yaitu $\pm 5000 \mathrm{~m}^{2}$ dengan populasi tanaman kopi sebanyak 833 tanaman dengan jarak tanam $2 \times 3$ meter.

\section{Perakitan Perangkap}

Perangkap tipe corong tunggal dibuat dengan menyusun corong 1 buah dan mengaitkan senyawa penarik yang sudah dibungkus dengan plastik yang diberi lubang (Gambar 1A). Senyawa penarik dikaitkan dengan menggunakan tali tepat di bawah penutup perangkap dan untuk menampung serangga yang tertangkap pada bagian ujung corong disambungkan dengan botol kocok yang telah diisi larutan deterjen dan alkohol. Hal yang 
sama dilakukan pada perangkap tipe corong ganda dengan menyusun corong secara bertingkat sebanyak 4 buah (Gambar 1B).

Perangkap dari botol bekas air mineral memiliki ukuran volume 1,5 liter. Selanjutnya pada botol tersebut dibuat dua celah pada sisi botol yang saling berhadapan dengan ukuran $5 \times$ $6 \mathrm{~cm}$ (Gambar 1C). Senyawa penarik digantungkan di dalam botol mineral dengan cara dikaitkan menggunakan tali pada bagian tutup botol di bagian atas, sedangkan untuk menampung serangga yang tertangkap diletakkan larutan deterjen dan alkohol pada bagian dasar botol.

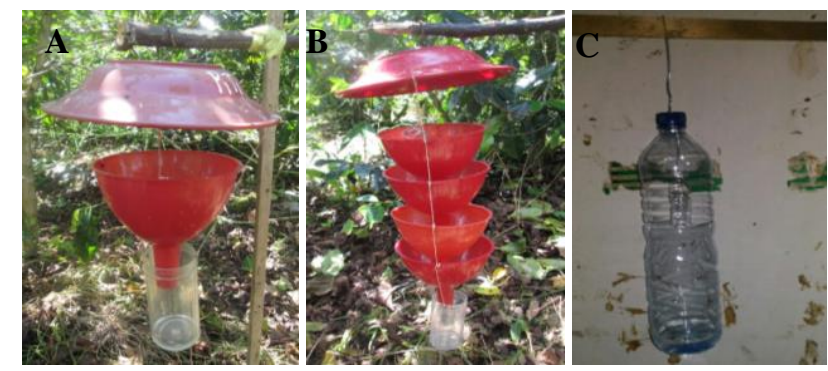

Gambar 1: Tipe Perangkap
A : Corong Tunggal
B : Corong Ganda
C : Botol Air Mineral

\section{Pemasangan Perangkap}

Perangkap digantung sesuai perlakuan diantara pohon kopi pada setiap ulangan dan dipasang secara acak pada areal pertanaman dengan jumlah 48 buah perangkap.

Peubah amatan terdiri dari :

\section{Jumlah imago penggerek buah kopi yang terperangkap}

Menghitung jumlah populasi imago penggerek buah kopi yang tertangkap pada masing-masing perlakuan dimana kombinasi perlakuan tipe perangkap. Perhitungan dilakukan setiap 2 hari sekali selama $7 \mathrm{x}$ pengamatan

\section{Serangga lain yang terperangkap}

Menghitung jumlah serangga lain yang terperangkap dan diidentifikasi sampai dengan tingkat famili dengan menggunakan buku panduan identifikasi serangga Borror et al. 1992. Perhitungan dilakukan bersamaan dengan menghitung jumlah PBKo yang terperangkap.

\section{Sisa larutan atraktan}

Menghitung sisa cairan atraktan pada masing-masing perlakuan yang terdapat pada wadah larutan setiap perangkap. Perhitungan dilakukan bersamaan dengan menghitung jumlah PBKo dan jumlah serangga lain yang terperangkap.

\section{HASIL DAN PEMBAHASAN}

\section{Jumlah imago penggerek buah kopi yang terperangkap}

Pengaruh tipe dan ketinggian perangkap terhadap jumlah imago penggerek buah kopi yang tertangkap dapat dilihat pada Tabel 1 .

Tabel 1. Pengaruh tipe dan ketinggian perangkap terhadap jumlah imago $H$. hampei yang tertangkap

\begin{tabular}{|c|c|c|c|c|c|}
\hline \multirow[t]{2}{*}{ Tipe } & \multicolumn{4}{|c|}{ Tinggi } & \multirow[t]{2}{*}{ Rataan } \\
\hline & $\mathrm{T} 1$ & $\mathrm{~T} 2$ & $\mathrm{~T} 3$ & $\mathrm{~T} 4$ & \\
\hline $\mathrm{P} 1$ & $13,5^{\mathrm{b}}$ & $19^{\mathrm{a}}$ & $9^{\mathrm{bc}}$ & $6^{\mathrm{c}}$ & $11,88^{b}$ \\
\hline $\mathrm{P} 2$ & $20^{\mathrm{a}}$ & $24,75^{\mathrm{a}}$ & $17,75^{\mathrm{a}}$ & $14^{\mathrm{a}}$ & $19,13^{\mathrm{a}}$ \\
\hline P3 & $27,5^{\mathrm{a}}$ & $10,75^{\mathrm{b}}$ & $6,75^{\mathrm{c}}$ & $4,25^{\mathrm{c}}$ & $12,31^{\mathrm{b}}$ \\
\hline Rataan & $20,33^{\mathrm{a}}$ & $18,17^{\mathrm{b}}$ & $1,17^{\mathrm{c}}$ & $8,08^{\mathrm{d}}$ & \\
\hline \multicolumn{6}{|c|}{$\begin{aligned} \text { Keterangan: } & \text { Angka dengan notasi huruf yang berbeda } \\
& \text { menunjukkan pengaruh yang nyata pada DMRT } \\
& \text { taraf } 5 \% . \mathrm{P} 1 \text { (tipe corong tunggal), P2 (tipe } \\
& \text { corong ganda), P3 (tipe botol air mineral), T1 } \\
& \text { (ketinggian } 60 \mathrm{~cm} \text { ), T2 (ketinggian } 120 \mathrm{~cm}), \mathrm{T} 3 \\
& \text { (ketinggian } 175 \mathrm{~cm}), \mathrm{T} 4 \text { (ketinggian } 200 \mathrm{~cm}) .\end{aligned}$} \\
\hline
\end{tabular}

Perlakuan P3T1 (tipe botol air mineral, ketinggian $60 \mathrm{~cm}$ ) menangkap penggerek buah kopi lebih banyak dengan rataan 27,5 ekor. Hasil ini berbeda dengan hasil penelitian Mathieu et al. (1997) tentang perangkap penggerek buah kopi yang menunjukkan bahwa faktor perangkap corong ganda (multiple funnel trap) dengan warna merah lebih banyak menarik serangga daripada perangkap warna putih. Namun sejalan dengan faktor perlakuan penempatan perangkap yang menunjukkan bahwa penggerek buah kopi lebih menyukai lokasi perangkap yang dekat dengan pohon dan ternaungi.

Pengamatan dilakukan pada tanaman kopi dengan ketinggian 1-3,5 meter. Perlakuan terbaik terdapat pada perlakuan P3T1 yaitu rataan jumlah penggerek buah kopi yang tertangkap dari awal hingga akhir pengamatan sebesar 27,5 ekor. Serangga dapat tertangkap pada pemasangan perangkap mulai dari ketinggian $60 \mathrm{~cm}$ sampai dengan ketinggian 2 meter karena pada ketinggian tersebut masih 
terdapat buah kopi dan tidak dilakukan pemangkasan pada ketinggian tersebut. Hasil percobaan ini juga didukung oleh hasil penelitian Sinaga (2015) yang menyatakan bahwa jumlah imago penggerek buah kopi tertinggi terdapat pada ketinggian $1,0 \mathrm{~m}$ karena karena buah kopi yang dominan berada di ketinggian tersebut. Perilaku penggerek buah kopi yang lebih menyukai tempat yang lembab dan ternaungi mendukung jumlah penggerek buah kopi banyak terperangkap pada ketinggian tersebut.

Ketinggian perangkap yang rendah dan tertutupi oleh tanaman kopi yang rimbun yang disukai oleh serangga penggerek buah kopi. Untung (2010) menyatakan bahwa PBKo mengarahkan serangan pertamanya pada bagian kebun kopi yang bernaungan, lebih lembab atau di perbatasan kebun. Serangga PBKo masih dapat terperangkap sampai dengan ketinggian 1,4 meter Manurung (2008), dan $175 \mathrm{~cm}$ Wiryadiputa (2006) karena pada ketinggian tersebut masih terdapat buah kopi yang setengah masak dan yang masak (berwarna merah) sehingga penggerek buah kopi dapat berkembang biak dengan baik di ketinggian tempat kurang dari $1200 \mathrm{~m} \mathrm{dpl}$ dan terperangkap, namun menurut CIRAD (2004) ketinggian perangkap yang efektif adalah 1,2 meter.

\section{Serangga lain yang terperangkap}

Pengaruh tipe dan ketinggian perangkap terhadap jumlah serangga lain yang terperangkap dapat dilihat pada Tabel 2 dan jumlah ordo/famili seranggga lain yang terperangkap dapat dilihat pada Tabel 3.

Tabel 2. Pengaruh tipe dan ketinggian perangkap terhadap jumlah serangga lain yang terperangkap

\begin{tabular}{|c|c|c|c|c|c|}
\hline \multirow[t]{2}{*}{ Tipe } & \multicolumn{3}{|c|}{ Tinggi } & & \multirow[t]{2}{*}{ Rataan } \\
\hline & $\mathrm{T} 1$ & $\mathrm{~T} 2$ & $\mathrm{~T} 3$ & $\mathrm{~T} 4$ & \\
\hline $\mathrm{P} 1$ & $7,0^{\mathrm{b}}$ & $12,3^{\mathrm{b}}$ & $9,3^{\mathrm{b}}$ & $12,8^{\mathrm{b}}$ & $10,3^{\mathrm{c}}$ \\
\hline $\mathrm{P} 2$ & $17,3^{\mathrm{a}}$ & $19,0^{\mathrm{a}}$ & $13,8^{\mathrm{ab}}$ & $10,3^{\mathrm{b}}$ & $15,1^{\mathrm{b}}$ \\
\hline P3 & $15,3^{\mathrm{a}}$ & $17,5^{\mathrm{a}}$ & $21,8^{\mathrm{a}}$ & $18,0^{\mathrm{a}}$ & $18,1^{\mathrm{a}}$ \\
\hline Rataan & $13,2^{\mathrm{d}}$ & $16,3^{\mathrm{a}}$ & $14,9^{\mathrm{b}}$ & $13,7^{\mathrm{c}}$ & \\
\hline & \multicolumn{5}{|c|}{$\begin{array}{l}\text { Angka dengan notasi huruf yang berbeda } \\
\text { menunjukkan pengaruh yang nyata pada DMRT } \\
\text { taraf } 5 \% \text {. P1 (tipe corong tunggal), P2 (tipe } \\
\text { corong ganda), P3 (tipe botol air mineral), T1 }\end{array}$} \\
\hline
\end{tabular}

(ketinggian $60 \mathrm{~cm}$ ), T2 (ketinggian $120 \mathrm{~cm}$ ), T3 (ketinggian $175 \mathrm{~cm}$ ), T4 (ketinggian $200 \mathrm{~cm}$ ).

Pengamatan selama 7 kali setelah pemasangan perangkap menujukkan bahwa rataan jumlah populasi jenis serangga lain yang tertinggi terdapat pada rataan perlakuan P3T3 (tipe botol air mineral, ketinggian $175 \mathrm{~cm}$ ) yaitu sebesar 21,8 ekor dan jumlah populasi terendah adalah perlakuan P1T1 (tipe corong tunggal, ketinggian $60 \mathrm{~cm}$ ) yaitu 7,0 ekor. Hal ini diduga karena wadah perangkap yang lebih lebar dan tinggi kemudian terdapat celah pada kedua sisinya sehingga membuat serangga lebih mudah masuk dan terperangkap serta didukung dengan senyawa atraktan yang diduga dapat menarik serangga lain. Hasil penelitian ini sedikit berbeda dengan penelitian Wiryadiputra (2006) yang menyatakan bahwa alat perangkap corong ganda adalah yang paling banyak menangkap jenis serangga selain. Corong ganda menangkap jenis serangga lain paling banyak karena dari aspek teknis dan dari segi peluang kesempatan, memang memungkinkan karena terdapat empat corong yang dikumpulkan menjadi satu dan serangga yang memiliki perilaku terbang cepat dan arah lurus akan menabrak perangkap dan jatuh pada corong yang selanjutnya masuk ke dalam botol penampung. Berbeda dengan tipe perangkap botol dengan lubang lurus, maka serangga yang terbang secara kebetulan dan tidak tertarik dengan senyawa perangkap akan sulit terperangkap.

Berdasarkan hasil penelitian keanekaragaman serangga lain diperoleh dari pengamatan, Hymenoptera famili formicidae sebanyak 231 ekor. Hal ini sesuai dengan penelitian Siregar dan Dewiyana (2016) yang menyatakan bahwa populasi Formicidae dan Scolytidae yang tinggi disebabkan oleh kesesuain habitat dan sumber makanan. 
Tabel 3. Jumlah serangga lain yang terperangkap selama 7 kali pengamatan

\begin{tabular}{|c|c|c|c|c|c|c|c|c|c|}
\hline \multirow[t]{2}{*}{ Ordo/Famili } & \multirow[b]{2}{*}{ I } & \multicolumn{6}{|c|}{ Pengamatan } & \multirow[t]{2}{*}{ Total } & \multirow{2}{*}{$\begin{array}{c}\text { Rata-rata } \\
\text { (ekor) }\end{array}$} \\
\hline & & II & III & IV & $\mathrm{V}$ & VI & VII & & \\
\hline \multicolumn{10}{|l|}{ Blattaria } \\
\hline Blattellidae & 59 & 39 & 2 & 3 & 6 & 6 & 5 & 120 & 17,14 \\
\hline \multicolumn{10}{|l|}{ Hymenoptera } \\
\hline Formicidae & 48 & 23 & 32 & 39 & 30 & 40 & 19 & 231 & 33 \\
\hline \multicolumn{10}{|l|}{ Coleoptera } \\
\hline Scolytidae & 71 & 40 & 212 & 105 & 102 & 92 & 82 & 704 & 100,57 \\
\hline Coccinellidae & 4 & 4 & 8 & 20 & 12 & 23 & 17 & 88 & 12,57 \\
\hline \multicolumn{10}{|l|}{ Orthoptera } \\
\hline Acrididae & 0 & 0 & 0 & 1 & 0 & 3 & 1 & 5 & 0,71 \\
\hline Gryllidae & 0 & 1 & 0 & 0 & 1 & 0 & 1 & 3 & 0,43 \\
\hline \multicolumn{10}{|l|}{ Araneae } \\
\hline Lycosidae & 2 & 0 & 1 & 0 & 2 & 0 & 3 & 8 & 1,14 \\
\hline \multicolumn{10}{|l|}{ Hemiptera } \\
\hline Alydidae & 3 & 1 & 1 & 0 & 3 & 2 & 4 & 14 & 2 \\
\hline \multicolumn{10}{|l|}{ Lepidoptera } \\
\hline Hesperlidae & 15 & 2 & 1 & 8 & 6 & 0 & 3 & 35 & 5 \\
\hline \multicolumn{10}{|l|}{ Isoptera } \\
\hline Termitidae & 1 & 0 & 0 & 0 & 0 & 0 & 0 & 1 & 0,14 \\
\hline \multicolumn{10}{|l|}{ Diptera } \\
\hline Culicidae & 55 & 65 & 4 & 4 & 9 & 16 & 15 & 168 & 24 \\
\hline Syriphidae & 2 & 3 & 1 & 0 & 0 & 1 & 0 & 7 & 1 \\
\hline Total & 189 & 138 & 50 & 75 & 69 & 91 & 68 & 680 & 97,14 \\
\hline
\end{tabular}

\section{Sisa larutan atraktan}

Pengaruh tipe dan ketinggian perangkap terhadap sisa larutan atraktan dilihat pada Tabel 3.

Tabel 3. Pengaruh tipe dan ketinggian perangkap terhadap sisa larutan atraktan

\begin{tabular}{|c|c|c|c|c|c|}
\hline \multirow[t]{2}{*}{ Tipe } & \multicolumn{3}{|c|}{ Tinggi } & & \multirow[t]{2}{*}{ Rataan } \\
\hline & $\mathrm{T} 1$ & $\mathrm{~T} 2$ & $\mathrm{~T} 3$ & $\mathrm{~T} 4$ & \\
\hline $\mathrm{P} 1$ & $10,60^{\mathrm{a}}$ & $10,30^{\mathrm{a}}$ & $15,03^{\mathrm{a}}$ & $10,43^{\mathrm{a}}$ & $11,59^{b}$ \\
\hline $\mathrm{P} 2$ & $10,13^{\mathrm{a}}$ & $10,38^{\mathrm{a}}$ & $9,50^{\mathrm{a}}$ & $9,38^{\mathrm{a}}$ & $9,84^{\mathrm{a}}$ \\
\hline P3 & $2,30^{\mathrm{b}}$ & $1,93^{\mathrm{b}}$ & $0,73^{\mathrm{b}}$ & $1,03^{\mathrm{b}}$ & $1,49^{\mathrm{c}}$ \\
\hline Rataan & $7,68^{\mathrm{b}}$ & $7,53^{\mathrm{bc}}$ & $8,42^{\mathrm{a}}$ & \multicolumn{2}{|l|}{$6,94^{\mathrm{c}}$} \\
\hline Keterang & \multicolumn{5}{|c|}{$\begin{array}{l}\text { Angka dengan notasi huruf yang berbeda } \\
\text { menunjukkan pengaruh yang nyata pada DMRT } \\
\text { taraf } 5 \% . \mathrm{P} 1 \text { (tipe corong tunggal), P2 (tipe } \\
\text { corong ganda), P3 (tipe botol air mineral), T1 } \\
\text { (ketinggian } 60 \mathrm{~cm} \text { ), T2 (ketinggian } 120 \mathrm{~cm} \text { ), T3 } \\
\text { (ketinggian } 175 \mathrm{~cm}), \text { T4 (ketinggian } 200 \mathrm{~cm} \text { ). }\end{array}$} \\
\hline
\end{tabular}

Pada pengamatan selama dua minggu diperoleh rataan sisa larutan atraktan yang tertinggi adalah pada perlakuan P1 (tipe corong tunggal) yaitu sebesar $11,59 \mathrm{ml}$ dan yang terendah adalah perlakuan P3 (tipe botol air mineral) yaitu sebesar $1,49 \mathrm{ml}$. Pada peubah amatan ini menunjukkan bahwa semakin banyak larutan atraktan yang tersisa pada perangkap maka artinya semakin sedikit yang menguap, sebaliknya apabila semakin sedikit sisa larutan atraktan artinya semakin banyak yang menguap.

Pada tipe perangkap P3 lebih sedikit larutan atraktan yang tersisa karena terbuat dari bahan plastik yang transparan dan diberi lubang pada sisi samping yang saling berhadapan serta didukung dengan letak ketinggian menyebabkan senyawa atraktan lebih cepat menguap ke udara. Jumlah serangga yang terperangkap berkaitan dengan jumlah senyawa yang menguap. Hal ini sesuai dengan liteatur Wiryadiputra (2006) mengenai penelitian alat perangkap yang digunakan untuk pengujian senyawa perangkap terhadap jumlah PBKo. Perangkap botol air mineral menangkap lebih banyak serangga PBKo dibandingkan dengan perangkap corong ganda. Pada tipe alat perangkap botol dengan lubang lurus, perolehan serangga PBKo yang tertangkap selama satu minggu lebih tinggi dibanding alat perangkap corong ganda. Perangkap yang dilengkapi dengan aroma biasanya menangkap lebih banyak serangga dibandingkan dengan yang tanpa aroma (Mathieu et al.,1999).

Penguapan yang tinggi pada tipe perangkap P3 (botol air mineral) didukung oleh sifat bahan perangkap yang terbuat dari plastik dan transparan. Cahaya yang masuk 
pada wadah transparan menyebabkan terjadinya penguapan alkohol lebih cepat. Berbeda dengan tipe perangkap P1 (corong tunggal) yang terbuat dari bahan plastik berwarna merah. Warna merah memilki panjang gelombang yang lebih panjang (650$700 \mathrm{~nm}$ ) (Djamas, 1993) atau memiliki frekuensi paling rendah dibandingkan dengan warna lainnya sehingga menyebabkan proses penguapan jauh lebih lambat

Beberapa studi menunjukkan bahwa PBKo yang tertangkap meningkat dengan menggunakan campuran bahan ethanol dan methanol dengan perbandingan tingkat campuran 1:3. Ketertarikan serangga PBKo terhadap perangkap juga dikarenakan senyawa atraktan seperti methanol, ethanol dan asam klorogenat (Siregar, 2016). Hal ini didukung oleh pernyataan Silva et al. (2006), PBKo yang merupakan famili Scolytidae tertarik pada ethanol dan methanol. Beberapa studi menunjukkan bahwa jumlah serangga PBKo yang tertangkap dapat meningkat dengan menggunakan campuran bahan ethanol dan methanol dengan perbandingan tingkat campuran 1:3 tetapi sedikit berbeda dengan literatur Messing (2012) yang menyatakan bahwa rataan perbandingan 1:1 lebih baik daripada 1:3 methanol dan ethanol merupakan perbandingan yang lebih baik terhadap PBKo yang terperangkap.

\section{SIMPULAN}

Tipe dan ketinggian perangkap terbaik dalam mengendalikan penggerek buah kopi terdapat pada perlakuan tipe botol air mineral, ketinggian $60 \mathrm{~cm}$ yaitu dengan rataan sebesar 27,5 ekor.

Tipe dan ketinggian perangkap terbaik terhadap serangga lain yang terperangkap adalah tipe botol air mineral, ketinggian 175 $\mathrm{cm}$ dengan rataan sebesar 21,8 ekor dan Formicidae merupakan famili terbanyak yaitu 231 ekor (rata-rata 33 ekor).

Tipe perangkap berpengaruh terhadap sisa larutan atraktan, dimana tipe botol air mineral ketinggian $175 \mathrm{~cm}$ merupakan tipe perangkap terbaik dengan sisa larutan atraktan sebesar $0,73 \mathrm{ml}$.

\section{DAFTAR PUSTAKA}

Borror D J, Triplehorn C A dan Johnson N F. 1992. Pengenalan Pelajaran Serangga. Edisi keenam. Soetiono Porto Soejono. Gajah mada University Press. Yogyakarta.

CIRAD. 2004. The Brocap Trap. Tree Crops Department Coffee Programme. France.

Djamas, D. 1993. Absorbsi Radiasi Matahari oleh Permukaan Berwarna. IKIP, Padang.

Kabupaten Dairi dalam Angka. 2014. Dinas Perkebunan Provinsi Sumatera Utara.

Kecamatan Sumbul Dalam Angka. 2016. Badan Pusat Statistik Kabupaten Dairi.

Malau S, Lumbanraja P, Naibaho B, Sumihar S T T, dan Simanjuntak R. 2012. Kajian Tentang Pengaruh Atraktan Dari Nabati Alami Lokal dan Buatan untuk Memerangkap Hama Penggerek Buah Kopi di Sumatera Utara. Badan Penelitian dan Pengembangan Provinsi Sumatera Utara. Medan.

Manurung V. 2008. Penggunaan Brocap Trap Untuk Pengendalian Penggerek Buah Kopi Hypothenemus hampei Ferr. (Coleoptera : Scolytidae) Pada Tanaman Kopi. [Skripsi]. Fakultas Pertanian Universitas Sumatera Utara. Medan.

Mathieu F, Brun L O, Marchillaud C \& Ferrot B. 1997. Trapping of The Coffee Berry Borer Hypothenemus hampei Ferr. (Col., Scolytidae) Within A Meshenclosed Environment: Interaction of Olfactory and Visual Stimuli. J. Appl. Ent. 121:181-186.

Messing R H. 2012. The Coffee Berry Borer (Hypothenemus hampei) Invades Hawaii: Preliminary Investigations on Trap Response and Alternate Hosts. University of Hawaii at Manoa, Kauai Agricultural Research Center, 7370 Kuamoo Rd., Kapaa, HI 96746, USA. Insects 3:640-652 
Panggabean E. 2011. Buku Pintar Kopi. PT. Agromedia Pustaka. Jakarta.

Philpott S M, Perfecto I and Vandermeer J. 2008. Effects of Predatory Ants on Lower Trophic Levels Across A Gradient of Coffee Management Complexity. Journal of Animal Ecology 77:505-511.

Riyanto. 2007. Kepadatan, Pola Distribusi dan Peranan Semut pada Tanaman di Sekitar Lingkungan Tempat Tinggal. Jurnal Penelitian Sains.10:2:241-253.

Schmitz O J. Hamback P A and Beckerman A P. 2000. Trophics Cascades in Terrestrial Symstems: A Review of The Effects of Carnivore Removals on Plants. American Naturalist 135:141-153.

Silva F C, Ventura M U, and Morales L. 2006. Capture of Hypothenemus hampei Ferr. (Coleoptera : Scolytidae) in Response to Trap Characteristics. Science Agriculture (Piracicaba, Brazil) 63(6):567-571.

Sinaga K M. 2015. Uji Ketinggian dan Tipe Perangkap untuk Mengendalikan Penggerek Buah Kopi (Hypothenemus hampei Ferr.) (Coleoptera : Scolytidae) di Desa Pearung Kabupaten Humbang Hasundutan. [Skripsi]. Fakultas Pertanian Universitas Sumatera Utara, Medan.

Siregar A Z. 2016. Bio-Ecology of Hypothenemus hampei In Coffee Plantation In Sumbul and Sidikalang Districts, Northern of Sumatera, Indonesia. Int. J. $A d v$. Res. 4(11):2051-2058

Siregar A Z dan Dewiyana H. 2016. The Use of Traps To Detect Hypothetamus hampei In Coffee Plantation In Dairi, North of Sumatra, Indonesia. International Journal of Scientific \& Technology Research 5:217-220.

Untung K. 2010. Diktat Dasar-dasar Ilmu Hama Tanaman. Jurusan Hama dan Penyakit Tumbuhan, Fakultas Pertanian UGM. Yogyakarta.
Way M J and Khoo K C. 1992. Role of Ants in Pest Management. Annual Review of Entomology 37:479-503.

Wiryadiputra S. 2006. Penggunaan Perangkap Dalam Pengendalian Hama Penggerek Buah Kopi (PBKo, Hyphotenemus hampei). Pusat Penelitian Kopi dan Kakao Indonesia. Pelita Perkebunan 22(2), 101-118. 